\title{
PERAN GURU SEBAGAI FASILITATOR DALAM PEMBELAJARAN IPA DI SEKOLAH DASAR
}

\author{
Sulistriani $^{1}$, Joko Santoso ${ }^{2}$, dan Srikandi Octaviani ${ }^{3}$ \\ ${ }^{1}$ FKIP, STKIP PGRI Metro \\ ${ }^{2}$ FKIP, STKIP PGRI Metro \\ ${ }^{3}$ FKIP, STKIP PGRI Metro \\ Surel: joko.spbsi@gmail.com
}

\begin{abstract}
The purpose of this study was to describe the teachers role as a facilitator in science learning in class III SDN 10 Metro Timur. This research is a qualitative research with a descriptive approach. This study uses data collection techniques of observation, interviews, and documentation. Data analysis used Millis and Hubberman analysis where the data collection steps were, data reduction, data display, and drawing conclusions. The results obtained from the teachers role as a facilitator in science learning in class III, obtained 34 events which included events in the pedagogical aspect, psychological aspect, and cognitive development aspect.
\end{abstract}

Keywords: teacher's role, facilitator, science lesson

\section{PENDAHULUAN}

Indonesia merupakan negara yang peduli terhadap pendidikan yang akan membawa perubahan untuk generasi selanjutnya, dengan memperoleh pendidikan sejak usia dini, maka masyarakat Indonesia percaya akan lebih memiliki kepribadiandan akhlak yang baik untuk masa depan yang cerah. Hal ini dapat kita lihat dalam UU No. 20 Tahun 2003 tentang sistem pendidikan nasional yang berbunyi bahwa:

"Pendidikan adalah usaha sadar dan terencana untuk mewujudkan suasana belajar dan proses pembelajaran agar peserta didik secara aktif mengembangkan potensi dirinya untuk memiliki kekuatan, spiritual keagamaan, pengendalian diri, kepribadian, kecerdasan, akhlak mulia, serta keterampilan yang diperlukan dirinya, masyarakat, bangsa, dan negara"

Guru yang akan memfasilitasi para siswa dalam proses belajar mengajar untuk mencapai tujuan pendidikan, yakni berhasilnya proses pembelajaran. Guru yang sangat berperan penting dalam hal membimbing dan mendidik para siswanya, serta gurulah yang lebih banyak tatap muka dengan siswa di kelasnya, dalam hal ini maka guru harus berperan sebagai fasilitator. Inilah makna fasilitator oleh Sanjaya dalam Samisih (2014: 64) yang menyatakan bahwa sebagai fasilitator guru harus berperan dalam memberikan pelayanan 


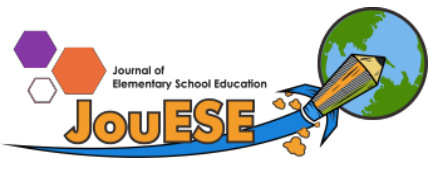

untuk memudahkan siswa dalam kegiatan prosespembelajaran. Oleh sebab itu, guru harus mampu menempatkan dirinya sebagai fasilitator dalam pembelajaran di kelas, serta harus mampu membimbing para siswa dan melayani siswa pada pedagogis serta psikologisnya agar siswa nyaman berkonsultasi tentang masalah atau materi yang kurang paham kepada guru tersebut.

Di sekolah dasar pendidikan IPA juga merupakan salah satu program pembelajaran yang bertujuan untuk menambahkan dan mengembangkan pengetahuan, keterampilan sikap, dan nilai ilmiah kepada siswa serta rasa mencintai dan menghargai kebesaran Tuhan Yang Maha Esa. Sehubungan dengan itu Khoirudin dalam Rini dan Made (2014: 68) mengemukakan bahwa tujuan pembelajaran IPA diajarkan di kelas adalah (1) mengembangkan kognitif siswa, (2) Mengembangkan afektif siswa, (3) mengembangkan psikomotorik siswa, (4) mengembangkan kreatif siswa, serta (5) melatih siswa berfikir kritis.

Peranan guru sebagai fasilitator sangat penting yakni, guru harus mampu membimbing siswa dalam hal pedagogis, seperti mampu menjelaskan atau menyampaikan materi pada siswa, lalu memfasilitasi psikologis siswa di kelas maupun luar kelas, dimana siswa yang mempunyai masalah atau tentang hal ketenangan dalam pembelajaran yang berhubungan dengan kejiwaan siswa tersebut dan terakhir guru mampu memfasilitasi siswa dalam hal kognitif siswa yakni guru harus mampu membuat siswa mudah dalam berfikir atau penalaran ketika proses bembelajaran. Guru akan mencapai keberhasilan tujuan pembelajaran ketika guru mampu memfasilitasi siswa dalam hal pedagogis, psikologis dan pengembangan kognitif siswa. Kenyataan yang ada di lapangan, guru hanya terfokus pada aspek pedagogisnya saja, dimana kurangnya guru dalam memfasilitai aspek psikologis dan aspek pengembangan kognitif siswa. Guru yang hanya menjelaskan lalu memberikan soal untuk dikerjakan siswanya, juga masih sering kita jumpai ketika dalam pembelajaran yang dilakukan oleh guru dan siswa di kelas.

Ketika penulis melakukan pra observasi di lapangan yakni SDN 10 Metro Timur, pada bulan Juli hingga Agustus, penulis melihat secara langsung bahwa guru yang masih kurang membimbing siswa yang sangat tertinggal dari yang lainnya, membiarkan siswa tersebut tidak memahami materi yang disampaikan dan hanya terfokus kepada siswa yang paham akan materi yang dijelaskan guru, terutama pada pembelajaran IPA. Jadi, masih banyaknya guru yang hanya menerangkan di depan kelas lalu memberikan soal, kemudian guru tersebut memberikan tugas untuk dikerjakan siswanya, itulah kenyataan di lapangan yang ditemukan 


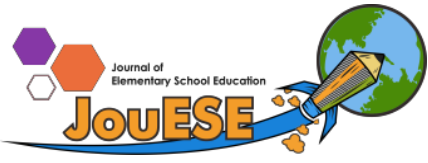

penulis. Peran guru sebagai fasilitator yakni guru harus berperan penting dalam pembelajaran yang dilakukan di kelas maupun di luar kelas.Sebagai fasilitator guru harus bisa memfasilitasi siswa dalam hal menyampaikan materi yang diembanya, guru harus memfasilitasi siswa dalam hal pedagogis, psikologis serta pengembangan kognitifnya.

\section{a. Pengertian Guru}

Guru merupakan salah satu komponen manusiawi dalam proses belajar mengajar, yang ikut berperan dalam usaha pembentukan sumber daya manusia yang profesional di bidang pendidikan. Oleh karena itu, guru yang merupakan salah satu unsur di bidang kependidikan harus berperan serta secara aktifdan menempatkan kedudukannya sebagai tenaga profesional, sesuai dengan dunia pendidikan yang semakin berkembang dan maju, dalam arti khusus dapat dikatakan bahwa pada setiap diri guru itu terletak tanggung jawab untuk membawa para siswanya pada suatu kedewasaan atau taraf kematangan tertentu.Iska dalam Umiyati (2013: 14) menyatakan bahwa:

"Guru sebagai pendidik tugasnya adalah mengajar, melatihdan memberikan bimbingan. Guru berperan memberikan bimbingan penguasaan nilai, disiplin diri, perencanaan masa depan, membantu mengatasi kesulitan yang dihadapi karena sedemikian besarnya tuntutan kehidupan dan masalah yang dihadapi, serta guru merupakan pendidik formal di sekolah".

Djamarah dalam Soangoa (2015: 6) menyatakan bahwa guru adalah sebagai pengelola kegiatan proses belajar mengajar, dalam hal ini, guru bertugas untuk mengarahkan kegiatan belajar siswa agar mencapai tujuan pembelajaran. Penjabaran tersebut dapat disimpulkan bahwa guru adalah orang yang memberikan pembelajaran dan pengajaran dalam bidang pendidikan, guru juga sebagai orang tua kedua siswa di sekolah, karena guru bertanggung jawab atas sikap dan hasil pembelajaran di sekolah. Guru juga sebagai fasilitator siswa untuk memberikan dan menyampaikan pembelajaran dengan baik agar tujuan dalam pembelajaran berhasil.

Pendapat tersebut, dapat penulis simpulkan bahwa guru adalah seorang yang tugasnya mengajar, melatih, membimbing, dan memberikan penilaian terhadap siswanya. Guru adalah seseorang yang bertugas untuk membantu siswanya jika siswa tersebut mengalami kesulitan belajar dan seorang pendidik yang identik dengan keberadaanya di sekolah.

\section{b. Peran Guru Sebagai Fasilitator}




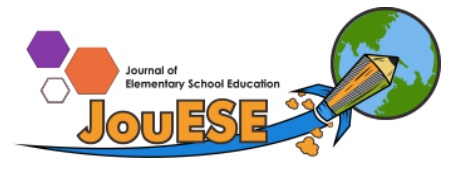

Fasilitator adalah seorang yang membantu siswa untuk belajar dan memiliki keterampilan-keterampilan yang diperlukan dalam mencapai tujuan pembelajaran. (Warsono dan Hariyanto 2013: 20) menyatakan bahwa sebagai fasilitator, guru menyiapkan fasilitas pedagogis, psikologis dan pengembangan kognitif siswanya. Fasilitas pedagogis menurut Suyono dan Hariyanto (2017: 16) yaitu ilmu atau seni dalam mengajar yang merujuk pada strategi pembelajaran atau gaya mengajar guru, dalam hal ini yang bersangkutan dengan penyampaian materi kepada siswa. Fasilitas psikologis guru yakni dapat diartikan sebagai salah satu cabang yang mengkaji tentang perilaku individu dalam konteks pendidikan, yaitu guru harus bisa membuat siswa tenang dalam perilakunya di sekolah, terutama saat proses pembelajaran berlangsung, dan guru harus mampu membuat siswa nyaman dengan tutur kata, tindak tunduk guru dalam proses pembelajaran. Terakhir yakni fasilitas dalam pengembangan kognitif siswa yaitu guru harus mampu membuat pembelajaran yang ada di kelas mampu dipahami oleh siswa dengan mudah, siswa mampu berfikir terhadap pembelajaran yang diberikan oleh guru kepada siswa.

Pendapat ahli tentang peran guru sebagai fasilitator yakni dapat disimpulkan bahwa, guru harus mampu memfasilitasi siswa dalam pembelajaran. Guru juga harus mampu membimbing siswa dan memberikan pengajaran sesuai dengan rencana pelaksanaan pembelajaran yang dibuat oleh guru. Serta guru harus mampu memberikan pelayanan serta kemudahan siswa pada saat pelaksanaan kegiatan belajar mengajar di kelas.

\section{c. Ilmu Pengetahuan Alam (IPA)}

Pembelajaran IPA di sekolah dasar merupakan suatu pembelajaran yang dapat menambah pengetahuan siswa di alam sekitarnya, yang diperoleh dari pengalaman melalui serangkaian proses ilmiah antara lain penyelidikan, penyusunan, dan pengujian gagasangagasan. Hal itu sesuai dalam Kurikulum Badan Standar Nasional Pendidikan (BSNP) dalam Dessriyanto (2013: 68) mengemukakakan bahwa, IPA berhubungan dengan cara mencari tahu tentang alam secara sistematis sehinga IPA bukan hanya penguasaan kumpulan pengetahuan yang berupa fakta-fakta, konsep-konsep atau prinsip-prinsip saja tetapi juga merupakan suatu proses penemuan. Rini dan Made (2014: 64) menyatakan bahwa IPA merupakan ilmu yang mempelajari peristiwa-peristiwa yang terjadi di alam. IPA membahas tentang gejala-gejala alam yang tersusun secara sistematis yang didasarkan pada hasil percobaan, dan pengamatan yang dilakukan oleh manusia. 


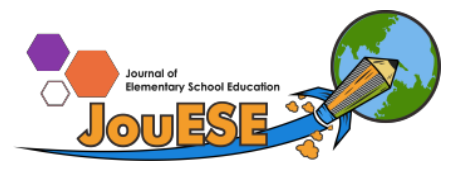

Berdasarkan penjelasan IPA tersebut maka dapat disimpulkan bahwa IPA itu adalah suatu pembelajaran dengan objek alam serta peristiwa-peristiwa alam. Pembelajaran IPA juga dapat diperoleh dengan cara pengamatan serta pengalaman langsung di lingkungan sekitar, IPA juga dapat dikatakan suatu cara atau metode langsung yang dapat digunakan untuk mengamati alam.

\section{METODE PENELITIAN}

Metode penelitian yang digunakan oleh penulis dalam penelitian ini adalah metode kualitatif. Penulis memilih metode penelitian Kualitatif dengan pendekatan deskriptif ini, karena sangat cocok dalam menafsirkan tentang peran guru sebagai fasilitator dalam pembelajaran IPA di kelas III SDN 10 Metro Timur. Dikarenakan dalam penelitian kualitatif ini pengumpulan datanya berbentuk kata-kata dan kalimat serta berlatar belakang alamiah. Penelitian ini dilakukan di SDN 10 Metro Timur, yang beralamatkan di Jl. Stadion Tejosari 24 metro. Obyek penelitian ini adalah guru kelas III B di SDN 10 Metro Timur. Penulis mengambil sumber data dari pengamatan yang dilakukan kepada beberapa orang yang terkait, yakni pendapat/argument obyek penelitian, pendapat/argument guru kelas III A, guru kelas III B semester lalu, pendapat/argument 2 siswa yang pernah menjadi siswa obyek penelitian.

Teknik pengumpulan data yang digunakan oleh penulis adalah dengan observasi, wawancara dan dokumentasi. Analisis data yang dilakukan selama di lapangan menggunakan model Miles Huberman yang meliputi reduksi data (reduction data), penyajian data (Data display), dan penarikan kesimpulan (Conclusion Drawing Verivication).

\section{HASIL DAN PEMBAHASAN}

Hasil penelitian yang penulis bahas ini tentang temuan yang ditemukan oleh penulis saat penelitian dilaksanakan. Berikut penulis akan membahas setiap peristiwa yang ditemukan oleh penulis.

\section{Pertemuan pertama}

a. Aspek Pedagogis

1) Gaya mengajar

\section{Peristiwa:}

Guru : Anak-anak sekarang kita lanjutkan materi yang kemarin ya.

Siswa : iya pak !!!! 
Guru : Materi yang sekarang akan kita bahas adalah tentang perubahan sifat benda, dimana benda-benda itu bersifat sifat padat, cair, dan gas. (guru sambil berjalan untuk melihat kesiapan siswa dalam belajar), kemudian perubahan yang terjadi jika padat ke cair dinamakan?

Gaya mengajar obyek penelitian pada pertemuan pertama yang ditemukan penulis saat observasi adalah gaya mengajar yang sedikit santai namun tegas, hal tersebut dapat dilihat dari notasi suara obyek penelitian saat menyampaikan materi. Gaya mengajar obyek penelitian pun disukai oleh siswanya, terlihat ketika obyek penelitian menyampaikan materi di depan kelas dan semua siswa bersikap kondusif, serta cara guru menyampaikan materi juga terlihat menyenangkan dimata anak-anak. Guru juga senantiasa berjalan mengelilingi siswa untuk melihat kesiapan belajar siswa.

\section{2) Metode pembelajaran}

\section{Peristiwa:}

Guru :....sekarang bapak membagikan kertas ini yang berupa soal, nanti masing-masing kelompok akan berdiskusi untuk membahas soal kelompok ini ya nak ...

Metode yang digunakan obyek penelitian ini adalah metode pembelajaran diskusi, berikut penulis sajikan pendapat ahli tentang metode diskusi. Djamarah dan Zain (2015: 87) menyatakan bahwa metode diskusi adalah cara penyajian pelajaran, dimana seluruh siswa dihadapkan pada suatu masalah yang bisa berupa pertanyaan atau pernyataan yang bersifat problematis untuk dibahas dan dipecahkan bersama. Pertemuan pertama ini penulis melihat bahwa obyek penelitian menggunakan metode diskusi untuk memecahkan masalah.

\section{3) Pendekatan pembelajaran}

\section{Peristiwa:}

Guru $\quad$....ya, yang seperti apa nak (sambil mendatangi siswa yang kurang paham)

Guru : ...gas itu bukan tabungnya ya nak, tapi isinya, begitu pun balon itu isinya nak, nah untuk sampai disini sekarang kita akan bagi kelompok ya nak, (guru mengawasi saat pembagian kelompok dengan mimik muka yang sangat akrab dengan anak-anak).

Penulis melihat bahwa pada pertemuan pertama obyek penelitian melakukan pendekatan yang bersifat individual atau perseseorangan, hal tersebut terlihat ketika obyek penelitian mendatangi siswa yang kurang paham menerima pembelajaran yang disampaikan oleh obyek penelitian. Pendekatan individual digunakan untuk mengatasi masalah-masalah di kelas, seperti pendapat Djamarah dan Zain (2015: 56) menyatakan bahwa pendekatan 


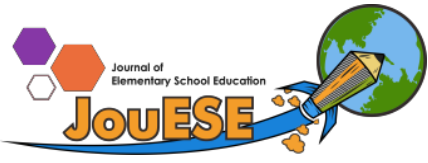

individual digunakan untuk mengatasi masalah yang timbul dalam kegiatan pembelajaran di kelas, seperti menghentikan siswa yang suka berbicara dengan memindahkan didekat anak yang pendiam. Hal tersebut juga dilakukan oleh obyek penelitian dalam menggunakan pendekatan individual.

Penulis melihat bahwa obyek penelitian setelah menggunakan pendekatan individual, obyek penelitian menggunakan pendekatan kelompok saat pembelajaran berkelompok berlangung. Pembelajaran berkelompok yang digunakan oleh obyek penelitian sangat efektif, walaupun dalam pelaksanaan pembelajaran berkelompok siswa sedikit ribut dengan kelompoknya masing-masing, namun siswa sangat antusias untuk bisa menjadi kelompok yang terbaik, seluruh kelompok berlomba-lomba untuk menjadi kelompok yang pertama menyelesaikan masalah yang diberikan oleh obyek penelitian tersebut, ketika ada kelompok yang kurang paham tentang masalah yang diberikan guru kekelompok, obyek penelitian langsung membantu menjelaskan kekelompok yang kurang paham agar dapat menyelesaikan masalah dengan kelompoknya sendiri.

\section{b. Aspek Psikologis}

\section{1) Pendekatan Terhadap Siswa Yang Kurang Mampu Menerima Pembelajaran}

\section{Peristiwa:}

Guru :...ayo nak dikerjakan dengan teliti. Semua anggota harus bekerja sama ya nak. (guru sambil berjalan mengelilingi semua siswanya untuk memfasilitasi kelompok yang kurang paham, dan ketika ada kelompok yang kurang paham guru tersebut langsung membantu menyelesaikan masalahnya).

Guru :...kerjakan ya nak, kemudian jika ada yang kurang paham tanyakan kepada bapak (sambil berjalan menuju dengan penuh senyum dan kasih sayang).

Pertemuan pertama ini, penulis menemukan dua peristriwa yang menunjukan bahwa obyek penelitian berperan sebagai fasilitator pada aspek psikologis ini, dimana guru harus mampu memfasilitasi siswa yang kurang mampu dalam menerima pembelajaran yang berlangsung di kelas. Guru harus mampu memfasilitasi siswa ketika belajar, berikut penulis sajikan makna belajar dalam pendapat ahli, Gagne dalam Suyono dan Hariyanto (2017: 12) menyatakan bahwa belajar adalah sebuah proses perubahan tingkah laku yang meliputi perubahan kecenderungan manusia seperti sikap, minat, atau nilai dan perubahan kemampuanya. Pendapat ahli tersebut menyatakan bahwa setelah belajar siswa harus memiliki perubahan, serta perubahan tersebut akan terjadi ketika guru mampu mefasilitasi 


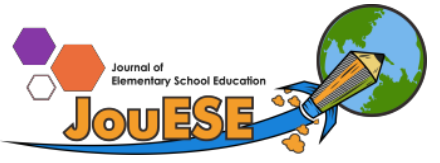

siswa dalam belajar di kelas, yakni mampu membuat nyaman dengan pendekatan secara psikologis dalam memfasilitasi siswa yang kurang mampu menerima pembelajaran yang berlangsung.

Obyek penelitian saat pendekatan dengan siswa yang kurang paham sangat luar biasa, beliau selalu memasang mimik muka yang sabar dan penuh perhatian kepada siswa atau kelompok yang kurang mampu menerima pembelajaran, dan obyek penelitian selalu berjalan mengelilingi siswa atau kelompok saat proses pembelajaran berlangsung untuk melihat proses siswa ketika menyelesaikan pembelajaranya.

\section{c. Pengembangan kognitif}

1) Membuat siswa mampu berfikir kritis dalam menyelesaikan pembelajaran, dan dorongan guru terhadap siswa untuk mampu menyampaikan pendapatnya di depan kelas.

\section{Peristiwa:}

Guru :...sekarang kelompok yang sudah siap untuk mendiskusikan hasil kerja kelompoknya, bisa maju di depan ya nak..

Guru :...sekarang untuk kelompok yang ingin menambahkan atau bertanya kepada kelompok 1, silahkan... disini bukan saatnya untuk takut ya nak, ayok untuk kelompok yang ingin mendapatkan nilai tambahan silahkan nak...

Pengembangan kognitif yang ditemukan oleh penulis pada pertemuan ini adalah bagaimana cara obyek penelitian mampu membuat siswa berfikir secara kritis dan siswa berani mengeluarkan pendapatnya di depan kelas. Guru harus mampu membuat siswa mengembangkan kognitifnya, berikut penulis sajikan pendapat tentang pengembangan kognitif, pernyataan Wundt dalam Suyono dan Hariyanto (2017: 73) menyatakan bahwa kognitif adalah hasil kreasi para siswa yang aktif dan kreatif yang kemudian disimpan dalam memori. Pendapat ahli tersebut menyatakan bahwa guru harus mampu membuat siswa berfikir secara kritis dalam mengembangkan kemampuanya, maka siswa akan selalu ingat hal tersebut jika guru selalu memberikan pernyataan yang positif kepada siswa.

Penulis melihat obyek penelitian selalu memberikan dukungan kepada siswa untuk selalu berani dalam menyampaikan pendapatnya di kelas. Obyek penelitian juga selalu menumbuhkan rasa untuk tidak takut dalam menyampaikan pendapatnya ke depan kelas.

\section{Pertemuan kedua}




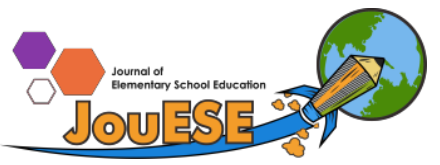

Pertemuan kedua ini, penulis melakukan obervasi di dalam kelas dengan cara merekam proses pembelajaran yang berlangsung di kelas. Pertemuan kedua ini penulis menemukan sembilan peristiwa, diantaranya, empat aspek pedagogis dan lima aspek psikologis, namun penulis hanya menyertakan dua penemuan setiap aspek sebagai contoh untuk dibahas oleh penulis. Pengamatan kedua ini penulis tidak menemukan aspek pengembangan kognitif. Berikut akan penulis bahas pada pertemuan kedua ini sebagai berikut:

\section{a. Aspek Pedagogis}

1) Media yang Digunakan

\section{Peristiwa:}

Guru : ...bapak membawa gambar contoh benda yang bersifat gas, benda cair,dan padat. Benda padat disini ada buku, pensil, kotak pensil dll, kemudian benda cair disini ada, sirup, minyak goreng, sabun cair, dll ..

Guru : ...iya nak, kemudian bapak juga membawa gambar contoh perubahan bendanya. ...

Pertemuan kedua ini, penulis melihat bahwa obyek penelitian telah menggunakan media pembelajaran sebagai pendukung berhasilnya pembelajaran. Media pembelajaran dalam pendapat Djamarah dan Zain (2015: 121) menyatakan bahwa media pembelajaran adalah alat bantu apa aja yang dapat dijadikan sebagai penyalur pesan guna mencapai tujuan pengajaran. hal tersebut membuat obyek penelitian menggunakan media pembelajaran, agar siswa tidak bosan dengan pembelajaran yang hanya terpaku pada guru saja.

Penulis melihat bahwa obyek penelitian mampu menggunakan media pembelajaran, media yang digunakan obyek penelitian adalah media gambar, dan media sesungguhnya yang ada disekitar siswa, hal tersebut digunakan oleh obyek penelitian agar siswa mampu menerima pembelajaran dengan mudah dari benda yang berada disekitar siswa. Obyek penelitian juga memberikan pernyataan saat melakukan wawancara dengan obyek penelitian, bahwa obyek penelitian selalu menggunakan media untuk menunjang keberhasilan pembelajaran serta mengantisipasi siswa untuk tidak jenuh dengan pembelajaran yang monoton.

\section{2) Bahasa Yang Mudah Dipahami}

\section{Peristiwa:}

Guru :...sekarang agar anak-anak lebih memahami materi tentang perubahan sifat benda, bapak ada contoh langsung benda padat,cair, dan gas nya berupa gambar ya nak....jadi 


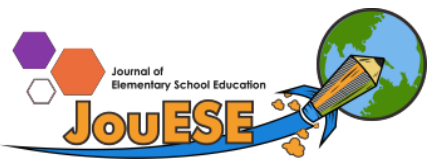

bapak membawa benda seperti ini, agar kalian lebih paham, akan adanya keberadaan benda itu memang ada dan banyak disekitar anak-anak.

Guru :...baik bapak akan menjelaskan perubahan sifat benda ya nak, terutama yang gas. Karena kalian yang belum paham adalah yang gas, terutama perubahan sifat bendanya. Air yang didihkan akan menjadi uap air. Uap air termasuk benda gas.Bentuknya tidak dapat kita lihat. Namun, kita dapat melihat uap air yang didinginkan, akan kembali menjadi air.

Bahasa yang digunakan oleh obyek penelitian pada pertemuan kedua ini sangat mudah dipahami oleh siswa, bahasa yang santai dan ringan akan membuat siswa paham dengan pembelajaran yang disampaikan oleh obyek penelitian, seperti halnya pendapat Syaifudin (2017: 60) menyatakan bahwa penjelasan hendaknya diberikan dengan menggunakan bahasa yang mudah dimengerti oleh siswa, dan menghindari penggunaan ucapan-ucapan serta istilah lain yang tidak dimengerti oleh siswa.

Penulis juga melihat bahwa obyek penelitian pada pertemuan kedua ini dalam pembelajaran sudah efektif dengan menggunakan bahasa yang mudah dipahami oleh siswa. Pernyataan tersebut mengungkapkan bahwa seorang guru harus memiliki kemampuan menggunakan bahasa yang mudah dipahami oleh siswanya. Guru juga harus mampu menjelaskan simbol serta ungkapan yang tidak dipahami oleh siswa ketika guru tersebut edang menyampaikan pembelajaran di depan kelas.

\section{b. Aspek Psikologis}

1) Pendekatan terhadap perilaku siswa yang kurang baik (terhadap temanya/siswa lain)

\section{Peristiwa:}

Guru : Merix, kenapa kamu buat ulah, sini maju kedepan untuk mempertanggung jawabkan perbuatanmu (guru menasehati merix dan reza tentang perbuatanya, tanpa menyinggung dan menyudutkan mereka).

Penulis menemukan aspek pikologis tentang pendekatan terhadap perilaku siswa yang kurang baik terhadap temanya atau siswa lainya, ketika penulis melakukan pengamatan di kelas penulis melihat bahwa ada siswa yang kurang berperilaku baik terhadap temanya, obyek penelitian langung menegur siswa yang bersangkutan tersebut untuk saling meminta maaf tanpa menyinggung dan menyudutkan salah satu siswa. Obyek penelitian sangat mengenal 


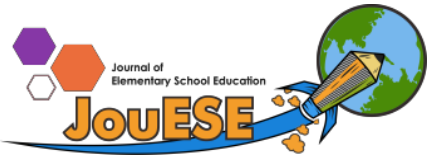

seluruh karakteristik sifat siswanya, dengan demikian beliau bisa mengatasi hal yang bersangkutan dengan aspek psikologis siswa.

\section{SIMPULAN}

Berdasarkan pembahasan pada Peran Guru Sebagai Fasilitator Dalam Pembelajaran IPA di kelas III SDN 10 Metro Timur, maka dapat disimpulkan bahwa Penulis telah melihat obyek penelitian mampu berperan sebagai fasilitator, dikarenakan objek penelitian dapat memenuhi ke 3 aspek tersebut, yaitu Aspek Pedagogis (gaya mengajar, strategi pembelajaran, metode pembelajaran, pendekatan pembelajaran, penggunaan media, dan penggunan bahasa yang mudah dipahami oleh siswa), Aspek Psikologis (pendekatan terhadap siswa yang berperilaku kurang sopan terhadap gurunya, pendekatan terhadap perilaku siswa yang kurang baik terhadap siswa lain, dan pendekatan terhadap siswa yang kurang paham menerima pembelajaran yang disampaikan oleh guru), dan Aspek Pengembangan Kognitif siswa (memudahkan siswa dalam penalaran terhadap pembelajaran yang disampaikan oleh guru, dan mendorong siswa untuk berfikir kritis dalam menyelesaikan masalah, serta dorongan guru agar siswa berani menyampaikan pendapatnya di depan kelas).

\section{DAFTAR PUSTAKA}

Dessriyanto, Fajar. 2013. Meningkatkan Kualitas Pembelajaran IPA melalui Model TGT pada siswa kelas V SD Kaliwaru Semarang.Universitas Negeri Semarang. (PDF : diakses 1, April 2017)

Djamarah, Bahri, Syaiful dan Zain, Aswan. 2015. Strategi Belajar Mengajar. Jakarta. Rineka Cipta

Hamzah, Mislawati. Peran Guru dalam Meningkatkan Motifasi Belajar Siswa Pada Mata Pelajaran IPS Kelas V SDN 5Telaga Kabupaten Guruntalo. Jurnal. 2013 (PDF : diakses 4, September 2017)

Hasanah, Nur. Dampak Kompetensi Profesional Guru dalam Meningkatkan Mutu Pendidikan MI di Kota Salatiga. Jurnal 9 (2).

Khodijah, Nyayu. 2017. PsikologiPendidikan. Jakarta. PT. Raja Grafindo Persada

Mudri, Walid. Kompetisi dan Peranan Guru dalam Pembelajaran. Jurnal Falasifa, 1(1).

Rusman.2014. Model-Model Pembelajaran. Jakarta PT. Raja Grafindo Persada.

Samisih. Pengaruh Guru Kelas dalam Menangani Kesulitan Belajar Siswa Sekolah Dasar Melalui Layanan Bimbingan Belajar. Jurnal Ilmiah Mitra Swara Ganesa.

Soangoa, Sintia. Peran Guru Mengelola Kelas dalam Mengoptimalkan Pembelajaran di Kelas IV SDN 36 Kota Selatan. Universitas Negeri Gorontalo Fakultas Ilmu Pendidikan Jurusan Pendidikan Guru Sekolah Dasar.Jurnal sintia soangoa. 2015 (PDF : diakses 12, April 2017)

Sugiyono. 2016. "Metode penelitian kuantitatif kualitatif dan kombinasi (Mixed Methods)". Bandung. Alfabeta 
Susanto, Ahmad. 2013. “Teori Belajar dan Pembelajaran di sekolah dasar”. Jakarta. Kencana

Suyono dan Hariyanto. 2017. "Belajar dan Pembelajaran”. Bandung.PT. Remaja Rosdakarya Offset.

Syaifudin. 2017. "Pengembangan Profesi Guru”. Bandung. Alfabeta

Tohirin. 2016. "Metode Penelitian Kualitatif dalam pendidikan dan Bimbingan Konseling”. Jakarta. PT. Raja Grafindo Persada. 